\title{
AMPLIFIKASI GEN CYTOCHROME OXIDASE SUBUNIT I (COI) DARI SAMPEL SIRIP IKAN HIU DENGAN MENGGUNAKAN BEBERAPA PASANGAN PRIMER
}

\section{(Amplification of Cytochrome Oxidase Subunit I (COI) Gene from Shark Fin Samples by Using Several Primer Pairs)}

\author{
Agustian Peloa $^{1^{\star}}$, Stenly Wullur ${ }^{1}$, Chatrien Anita Sinjal ${ }^{1}$
}

\author{
1. Program Studi IImu Kelautan, Fakultas Perikanan dan IImu Kelautan, Universitas Sam \\ Ratulangi, Manado \\ *e-mail :agustian.peloa.fpik2010@gmail.com
}

The study was conducted with the aims to isolate genomic DNA and to amplify COI (Cytochrome Oxidase Subunit I) gene from shark fin. Four shark fin samples of different individuals were obtained from fishermen in Tumbak village, Southeast Minahasa regency. DNA genome of the samples was isolated using protocol from InnuPREP DNA Mini Kit. COI gene was amplified in PCR (Polymerase Chain Reaction) using several primers; FishF1, FishBCL5, LCO1490 (forward) and HCO2198 (reverse). Genomic DNA of each sample was successfully isolated, which is indicated by a strong bands yielded from each sample. Amplification of COI gene using PCR shows that shark fin samples; SP2, SP3 and SP4 were successfully amplified using primers FishBCL5 (for) and HCO2198 (rev), while sample SP1 was successfully amplified using all primers used in this study. The bands yielded were differ among samples but appeared at the correct position (600 - 700 bp)

Keywords: Shark fin, Amplification, COI gene, Primer

Penelitian ini dilakukan dengan tujuan untuk mengisolasi DNA genom dan mengamplifikasi gen $\mathrm{COI}$ (Cytochrome Oxidase Subunit I) dari sirip ikan hiu. Empat sampel sirip ikan hiu dari individu yang berbeda didapatkan dari nelayan yang ada di desa Tumbak, Kabupaten Minahasa Tenggara. DNA genom dari sampel diisolasi menggunakan protokol dari InnuPREP DNA Mini Kit. Gen COI diamplifikasi dengan PCR (Polymerase Chain Reaction) dengan menggunakan beberapa primer; FishF1, FishBCL5, LCO1490 (forward) dan HCO2198 (reverse).DNA genomik dari masing-masing sampel berhasil diisolasi, yang ditandai dengan adanya pita DNA yang jelas dari masing-masing sampel. Amplifikasi gen COI menggunakan PCR menunjukkan bahwa sampel sirip ikan hiu; SP2, SP3 dan SP4 berhasil diamplifikasi menggunakan primer Fish BCL5 (for) dan HC02198 (rev), sedangkan sampel SP1 berhasil diamplifikasi dengan menggunakan semua primer dalam penelitian ini. Pita DNA yang dihasilkan berbeda namun muncul pada posisi yang benar (600 - $700 \mathrm{bp})$

Kata kunci: Sirip ikan hiu, Amplifikasi, Gen COI, Primer

\section{PENDAHULUAN}

DNA Barcoding adalah sebuah metode identifikasi spesies secara cepat dengan menggunakan urutan pendek DNA sebagai alat pengidentifikasiannya (Hebert et al., 2003). Salah satu manfaat DNA Barcoding adalah pengawasan kegiatan penangkapan dan perdagangan spesies yang menjadi komoditas perikanan dengan kaitannya pada usaha konservasi spesies yang dilindungi. Contohnya adalah ikan hiu (Kurniasih, 2013).

Menurut Holmes et al. (2008), data rujukan sebagai dasar manajemen konservasi spesies ikan hiu sulit didapatkan karena umumnya ikan hiu diperdagangkan dalam bentuk sirip sehingga proses identifikasi yang dilakukan menggunakan metode berbasis morfologis sangat sulit dilakukan.

Pengidentifikasian spesies ikan hiu menggunakan DNA Barcoding 
membutuhkan isolasi DNA genomik dan amplifikasi gen Cytochrome oxidase subunit I (COI) sebagai tahap awalnya (Holmes et al. 2008). Khusus pada tahap amplifikasi gen, terdapat sebuah komponen penting penentu utama keberhasilan proses amplifikasi gen yang disebut primer. Namun, belum diketahui primer manakah yang paling tepat untuk mengamplifikasi gen COI dari sirip ikan hiu. Penelitian ini bertujuan untuk mengisolasi DNA genom dari mengamplifikasi gen $\mathrm{COI}$ dari sampel sirip ikan hiu.

\section{METODE PENELITIAN}

Sampel berupa sirip ikan hiu kering didapatkan dari nelayan di Desa Tumbak, Kecamatan Pusomaen, Kabupaten Minahasa Tenggara. Menurut keterangan nelayan penjual, sirip ikan hiu ini didapatkan dari hasil penangkapan di perairan sekitar Sulawesi Utara. Sampel yang didapatkan berjumlah 16 potong. Sirip tersebut terbagi atas 4 ikat, setiap ikat terdapat 4 sirip, yang menandakan bahwa keempat ikat sirip berasal dari 4 individu yang berbeda. Sampel diisi di dalam plastik sampel, ditulis label untuk menjadi tanda dan dibawa ke Laboratorium Biologi Molekuler dan Farmakologi Kelautan FPIK UNSRAT untuk penelitian selanjutnya.

Prosedur penelitian dimulai dari tahap isolasi DNA genomik, kemudian amplifikasi gen COI dan terakhir elektroforesis gel (Gambar 2).

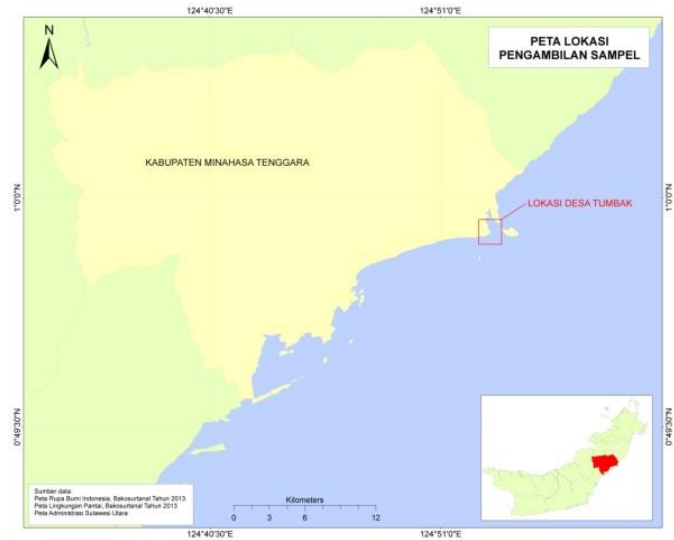

Gambar 1. Lokasi pengambilan sampel.

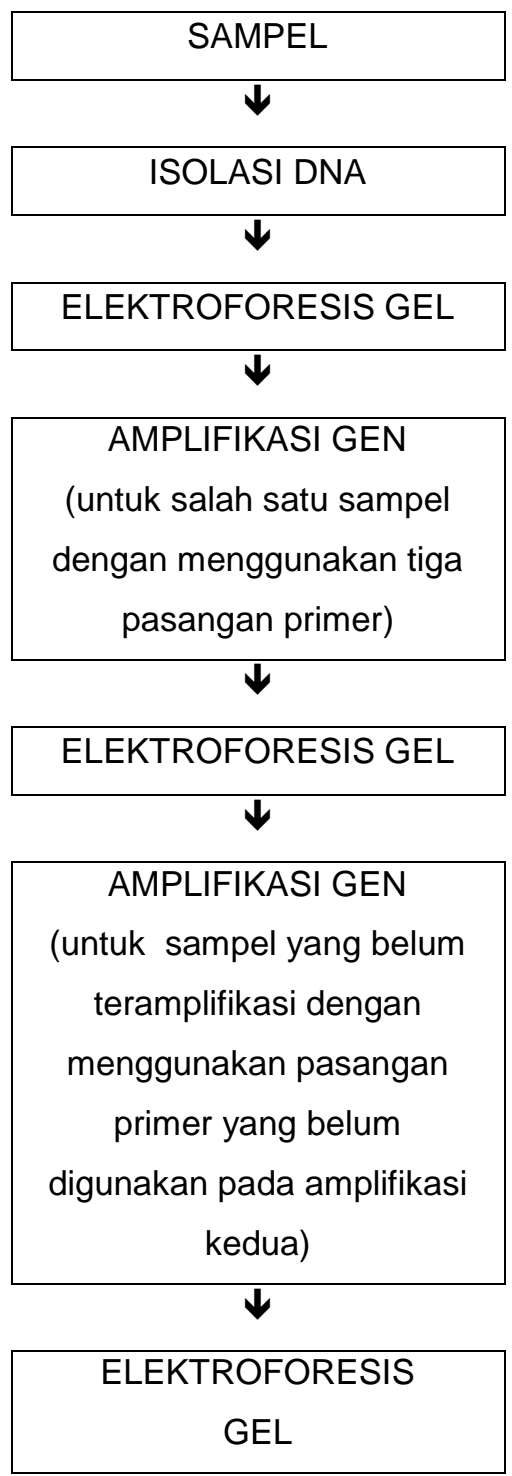

Gambar 2. Alur kerja penelitian.

Sampel sirip yang dipilih adalah sirip punggung. Tahap isolasi DNA genomik mengikuti protokol dari InnuPREP DNA Mini Kit (Analytic Jena). Pada serangkaian prosedur ini, DNA genomik dari sirip ikan hiu diisolasi melalui proses pemisahan secara mekanik dan kimiawi. Proses ini terjadi mulai dari lisis sel, pemisahan protein, garam dan komponen penyusun sel lainnya, dan terakhir, proses elusi/pengumpulan DNA.

Selanjutnya adalah tahap amplifikasi gen COI yang di dalamnya melibatkan metode PCR (Polymerase Chain Reaction). Gen COI dari masing- 
masing DNA genomik sampel diuji untuk diamplifikasi dengan 3 (tiga) pasangan primer: FishF1-HCO2198 (Kode: P1), FishBCL5-HCO2198 (Kode: P2), dan LCO1490-HCO2198 (Kode: P3).

$$
\text { Untuk menguji penggunaan } 3
$$

(tiga) pasangan primer, maka campuran reaksi PCR yang dibuat berarti berjumlah 3 (tiga), dimana masing-masing campuran ini menggunakan sampel DNA yang sama namun yang membedakannya adalah pasangan primer yang dicampurkan pada masing-masing campuran reaksi PCR tersebut. Untuk menguji penggunaan 1 (satu) pasangan primer, maka campuran reaksi PCR yang dibuat berarti berjumlah 4 (empat), dimana masing-masing campuran ini menggunakan primer yang sama namun yang membedakannya adalah sampel DNA genom yang dicampurkan pada masing-masing campuran reaksi PCR tersebut.

Masing-masing tahap yaitu isolasi DNA genomik dan amplifikasi gen COI membutuhkan pengujian elektroforesis gel untuk mengetahui keberhasilan dari tahap yang sudah dilakukan. Munculnya keberadaan pita DNA yang jelas merupakan tanda keberhasilan dari isolasi DNA genomik dan amplifikasi gen $\mathrm{COI}$ yang dilakukan. Khusus untuk amplifikasi gen COI dari sirip ikan hiu, keberhasilan amplifikasi juga dilihat berdasarkan kemunculan pita DNA pada posisi panjang basa 700 bp.

\section{HASIL DAN PEMBAHASAN}

\section{Koleksi dan Penanganan Sampel}

Pemilihan potongan sirip punggung dilakukan untuk menghindari terjadinya kekeliruan pengambilan sampel pada individu yang sama karena sirip punggung tidak terdapat dalam bentuk berpasangan. Selain itu, sirip punggung teramati memiliki lebih banyak jaringan otot yang tersisa dibandingkan sirip yang lainnya.

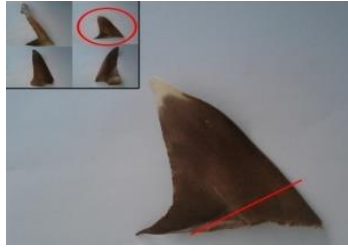

Kode : SP1

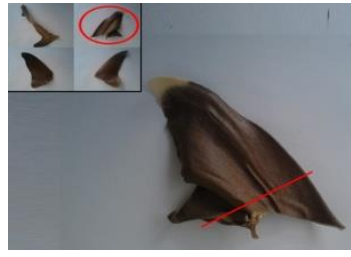

Kode : SP2

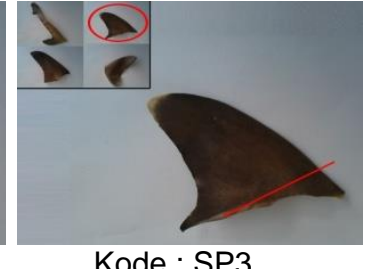

Kode : SP3

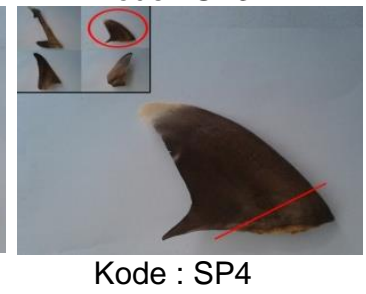

Gambar 3. Sampel sirip ikan hiu yang menjadi objek penelitian.

\section{Isolasi DNA}

Hasil isolasi DNA genomik dari sampel sirip ikan hiu yang dideteksi dengan menggunakan gel agarose ditampilkan pada gambar 4.

Hasil menunjukkan bahwa DNA genom dari semua sampel berhasil diisolasi meskipun terdapat DNA genom yang berkualitas kurang baik yaitu sampel nomor 2 dan 3 . Menurut Westermeier (2005), ini merupakan akibat dari kurang baiknya proses isolasi DNA yang terjadi pada saat

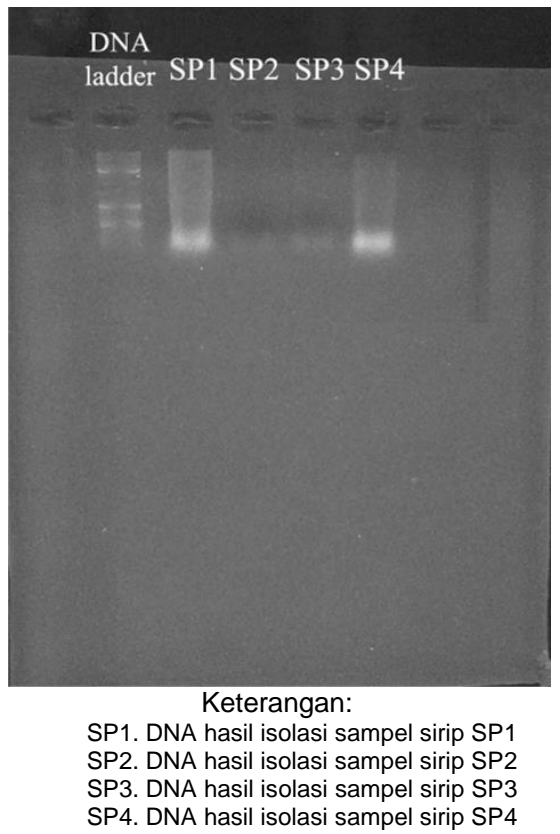

Gambar 4. Visualisasi dari hasil isolasi DNA genom semua sampel. 
pelaksanaan prosedur isolasi khususnya dalam tahap lisis sel.

\section{Amplifikasi gen COI dan Elektroforesis Gel}

Visualisasi produk PCR hasil amplifikasi gen COI dari sampel sirip ikan hiu SP4 yang diamplifikasi dengan menggunakan tiga pasangan primer yang berbeda (FishF1-HCO2198, FishBCL5-HCO2198, LCO1490HCO2198) dengan menggunakan gel agarose ditampilkan pada Gambar 5 .

Hasil analisa elektroforesis gel menunjukkan bahwa primer FishBCL5 (forward) dan HCO2198 (reverse) berhasil mengamplifikasi gen COI dari sampel sirip ikan hiu, ditandai dengan adanya tampilan pita DNA pada jalur lintasan gel untuk sumur nomor SP4+P2 (Gambar 5).

Primer FishBCL5 (forward) dan HCO2198 (reverse) yang berhasil mengamplifikasi gen COI pada sampel SP4 ini selanjutnya digunakan untuk mengamplifikasi sampel sirip lainnya

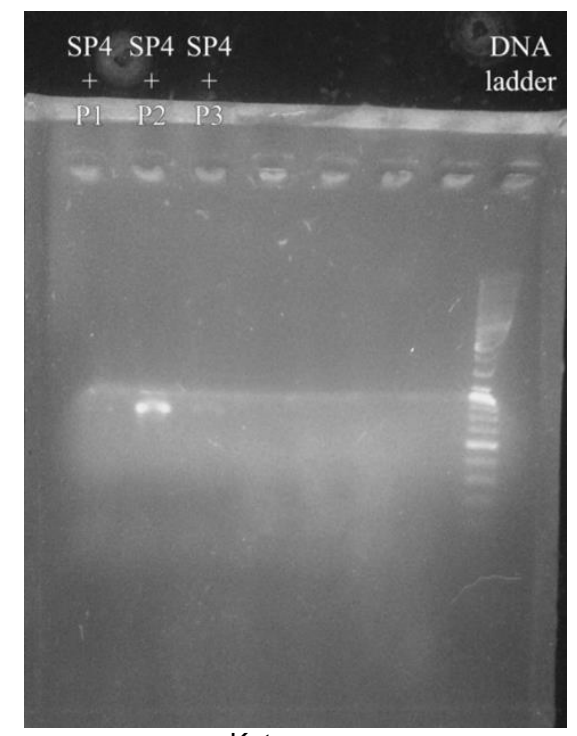

SP4+P1. Sampel sirip SP4 diamplifikasi dengan primer P1 SP4+P2. Sampel sirip SP4 diamplifikasi dengan primer P2 SP4+P3. Sampel sirip SP4 diamplifikasi dengan primer P3

Gambar 5. Visualisasi produk PCR hasil amplifikasi gen $\mathrm{CO}$ dari sampel sirip SP4 menggunakan semua pasangan primer.

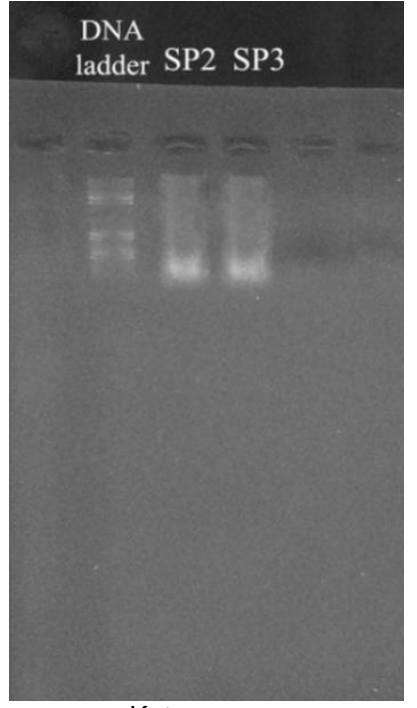

Keterangan:

SP2. DNA hasil isolasi sampel sirip SP2 SP3. DNA hasil isolasi sampel sirip SP3

Gambar 6. Visualisasi dari hasil isolasi ulang DNA genom sampel sirip SP2 da SP3.

yaitu SP1, SP2, dan SP3. Sehubungan dengan hasil isolasi genomik pada sampel sirip SP2 dan SP3 yang kurang baik (Gambar 4), maka kedua sampel tersebut dilakukan isolasi ulang untuk mendapatkan kualitas DNA genomik yang lebih baik. Hasil isolasi ulang DNA genom sampel sirip SP2 dan SP3 ditampilkan pada gambar 6

Keempat sampel sirip ikan hiu yang memiliki kualitas DNA genom yang baik selanjutnya digunakan untuk mengamplifikasi gen target (COI) dengan menggunakan pasangan primer P2. Penggunaan primer P2 pada tahap ini didasarkan pada keberhasilan pasangan primer ini dalam mengamplifikasi gen COI pada sampel sirip SP4.

Hasil visualisasi produk PCR sampel SP1, SP2, SP3 dan SP4 menggunakan primer P2 ditampilkan pada Gambar 7.

Produk PCR hasil amplifikasi gen COI dari sampel sirip ikan hiu SP1, SP2, SP3 dan SP4 menggunakan primer P2 menunjukkan bahwa jenis primer ini mampu mengamplifikasi gen 


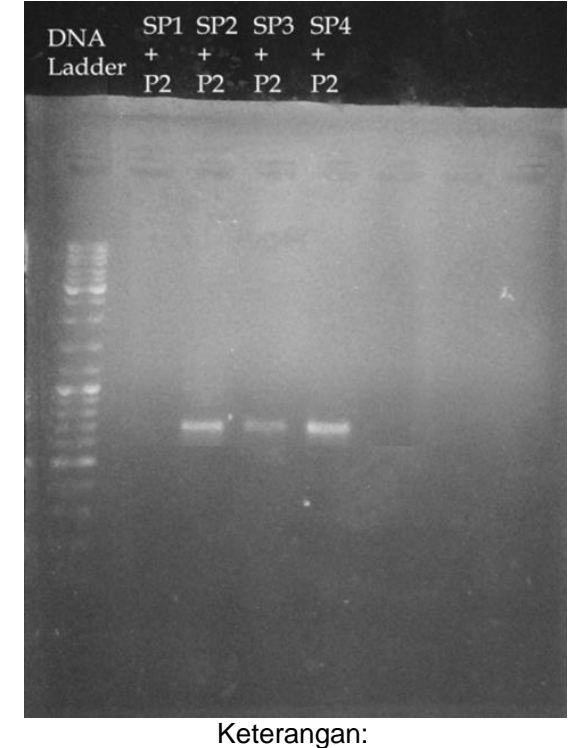

SP1+P2. Sampel sirip SP1 diamplifikasi dengan primer P2 SP2+P2. Sampel sirip SP2 diamplifikasi dengan primer P2 SP3+P2. Sampel sirip SP3 diamplifikasi dengan primer P2 SP4+P2. Sampel sirip SP4 diamplifikasi dengan primer P2

Gambar 7. Visualisasi produk PCR hasil amplifikasi gen $\mathrm{COI}$ dari semua sampel sirip menggunakan pasangan primer P2.

COI dari sampel sirip SP2, SP3 dan SP4 yang ditandai oleh adanya pita pada masing-masing lintasan sumur sampel tersebut. Sedangkan, pada lintasan sumur sampel sirip SP1 tidak terdapat tampilan pita DNA yang berarti amplifikasi tidak terjadi.

Amplifikasi gen COI pada sampel sirip SP1 selanjutnya dilakukan dengan menggunakan pasangan primer $\mathrm{P} 1, \mathrm{P} 2$ dan P3. Hasil amplifikasi gen COI dari sampel sirip SP1 menggunakan pasangan primer $\mathrm{P} 1, \mathrm{P} 2$ dan $\mathrm{P} 3$ yang dideteksi dengan menggunakan teknik elektroforesis gel ditampilkan pada Gambar 8.

Hasil elektroforesis dari amplifikasi ini menunjukkan bahwa semua primer berhasil mengamplifikasi gen COI pada sampel SPI, meskipun ketebalan pita DNA pada masingmasing sampel berbeda. Slater et al. (1989) menjelaskan bahwa perbedaan intensitas pita yang dihasilkan merupakan refleksi dari kuantitas gen yang berhasil diamplifikasi.

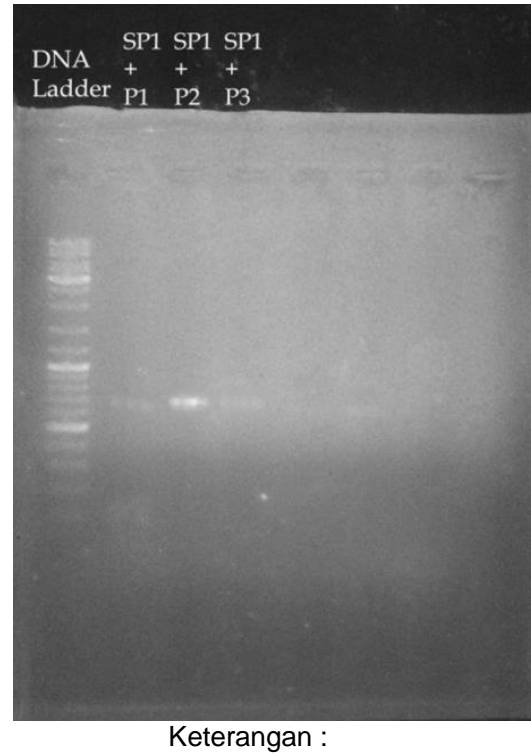

SP1+P1. Sampel sirip SP1 diamplifikasi dengan primer P1 SP1+P2. Sampel sirip SP1 diamplifikasi dengan primer P2 SP1+P3. Sampel sirip SP1 diamplifikasi dengan primer P3

Gambar 8. Visualisasi produk PCR hasil amplifikasi gen COI dari sampel sirip SP1 menggunakan semua pasangan primer (P1, P2, dan P3).

Gen COI hasil amplifikasi dari masing-masing sampel ikan hiu teramati muncul pada posisi 600 - 700 $\mathrm{bp}$, sesuai dengan yang dilaporkan dalam Hebert et al. (2003).

\section{KESIMPULAN}

DNA genom dari sirip ikan hiu berhasil diisolasi menggunakan InnuPREP DNA Mini Kit. Gen COI sampel sirip ikan hiu SP2, SP3 dan SP4 berhasil diamplifikasi menggunakan pasangan primer Fish BCL5 (for) dan HCO2198 (rev), sedangkan sampel SP1 dapat diamplifikasi menggunakan semua pasangan primer yang digunakan dalam penelitian ini, yang ditandai dengan munculnya pita pada posisi panjang basa $600-700 \mathrm{bp}$.

\section{DAFTAR PUSTAKA}

Hebert, P.D.,. Cywinska, A., Ball, S.L. 2003. Biological identifications through DNA barcodes. 
Proceedings of the Royal Society of London. Series B : Biological Sciences, 270 (151), 313-321.

Holmes, B.H., Steinke, D., Ward, R.D. 2008. Identification of shark and rays fins using DNA Barcoding. Fisheries Research, 95(2), 280288.

Kurniasih, E.M. 2013. DNA Barcoding dan Analisis filogenetik ikan hiu yang didaratkan di Pelabuhan Perikanan Samudera Cilacap. Skripsi. Fakultas Perikanan dan IImu Kelautan. Institut Pertanian Bogor.

Slater, G. W., Turmel, C., Lalande, M., Noolandi, J. 1989. DNA gel electrophoresis: effect of field intensity and agarose concentration on band inversion. Biopolymers, 28 (10), 1793-1799.

Westermeier, R. 2005. Electrophoresis in Practice: A Guide to Methods and Applications of DNA and Protein Separations, Fourth Edition .Wiley-VCH Verlag $\mathrm{GmbH}$ \& Co. Weinheim. 